\section{Carsten Lüter}

Museum für Naturkunde der Humboldt-Universität zu Berlin, Institut für Systematische Zoologie, Invalidenstrasse 43 , D-10115 Berlin, Germany Email: carsten.lueter@ museum.hu-berlin.de

submitted November 2003 accepted August 2004

\section{The first Recent species of the unusual brachiopod Kakanuiella (Thecideidae) from New Zealand deep waters}

\begin{abstract}
A new thecideid brachiopod species Kakanuiella chathamensis sp. nov. is described from deep waters on the Chatham Rise, east of South Island, New Zealand. The new species bears an unusual character combination in the shell morphology of its dorsal valve, displaying a mixture of diagnostic characters of both Recent thecideid subfamilies Thecidellininae and Lacazellinae. The resultant consequences for the systematic position of the genus Kakanuiella are discussed.
\end{abstract}

Key words Brachiopoda, Thecideidae, Kakanuiella chathamensis sp. nov., New Zealand, deep sea, Recent

\section{Introduction}

Thecideid brachiopods have a worldwide distribution and are well known for their preference for warm water conditions and cryptic habitats like caves and crevices in coral reefs or the undersides of corals (see Pajaud, 1970, 1974). Eleven extant species within four genera Lacazella, Thecidellina, Pajaudina and Ospreyella have been described. Their position within the brachiopod phylogeny is uncertain. There has been considerable debate whether spiriferides (Williams, 1968, 1973; MacKinnon, 1974), strophomenides (Pajaud, 1970; Grant 1972) or davidsonioids (Rudwick, 1968) were the ancestral flock thecideid brachiopods evolved from. Baker $(1984,1990)$ discussed all relevant morphological data of these groups in comparison to the shell morphology of thecideid brachiopods and confirmed early suggestions of a spiriferide ancestor for the group. More recently, Jaecks (2001) and Jaecks \& Carlson (2001) discussed strophomenide or spiriferide ancestry of thecideid brachiopods based on shell characters, but excluded a relationship with terebratulids. The latter was originally suggested by Cohen \& Gawthrop (1997) and Cohen et al. (1998) using molecular data, but later these results were qualified due to possible PCR artefacts (Cohen, pers. comm.). Usually, extant thecideid brachiopods are divided into two subfamilies, i.e. Thecidellininae Elliott, 1953 with a single genus Thecidellina, and Lacazellinae Backhaus, 1959 with the remaining three genera (Baker, 2004). Most diagnostic characters are provided by the inner sculpture of the dorsal valve of the shell. Thecideid brachiopods brood their larvae in one or two brood pouches (Lacaze-Duthiers, 1861; Pajaud, 1970; Lüter, pers. obs.). This brood-protecting behaviour is a consequence of production of only a few eggs and larvae and ensures survival of offspring through large amounts of yolk per egg, resulting in lecithotrophic larvae, and rather long duration of parental care.
Brood protection in thecideid brachiopods is associated with certain morphological structures even in the hard shell (Logan, 1988; Lüter et al. 2003). All groups within Lacazellinae show sexual dimorphism. Females have a single, median brood pouch in the mantle of the ventral valve. Larvae, protected in the pouch, cling to the tips of two specialized lophophoral tentacles (Lacaze-Duthiers, 1861; Lüter, pers. obs.; Logan, pers. comm.), which bend backwards and run through a hole - the so-called marsupial notch - in the bridge of the dorsal valve's brachidial sculpture before entering the brood pouch. The marsupial notch, specialized tentacles and the median brood pouch in the ventral mantle are a functional unit and a diagnostic character complex for Lacazellinae. This combination of characters is unique and is not present in Thecidellina. Instead, all six species within Thecidellina have two brood pouches in the dorsal mantle in holes of both interbrachial lobes on either side of the median ridge.

The new species described in this paper is the first thecideid brachiopod recorded from deep water $(\sim 1000 \mathrm{~m}$ depth). Its brachial valve morphology shows a mixture of diagnostic characters of both subfamilies Thecidellininae and Lacazellinae and, therefore, its phylogenetic position remains unclear. Almost identical morphological features as reported here have recently been described (Lee \& Robinson, 2003) in the Eocene-Oligocene fossil Kakanuiella hedleyi (Thomson, 1915), which, in the present state of knowledge, must be regarded as the $\sim 35$ million year old, extinct sister species of Kakanuiella chathamensis sp. nov, the new deep-sea thecideid from New Zealand waters.

\section{Materials and methods}

Hundreds of specimens (dead shells and living animals) were dredged at three Stations 73, 83 and 96 (see Fig. 1 and Table 1 for details) east of Chatham Island and on the Chatham Rise, 


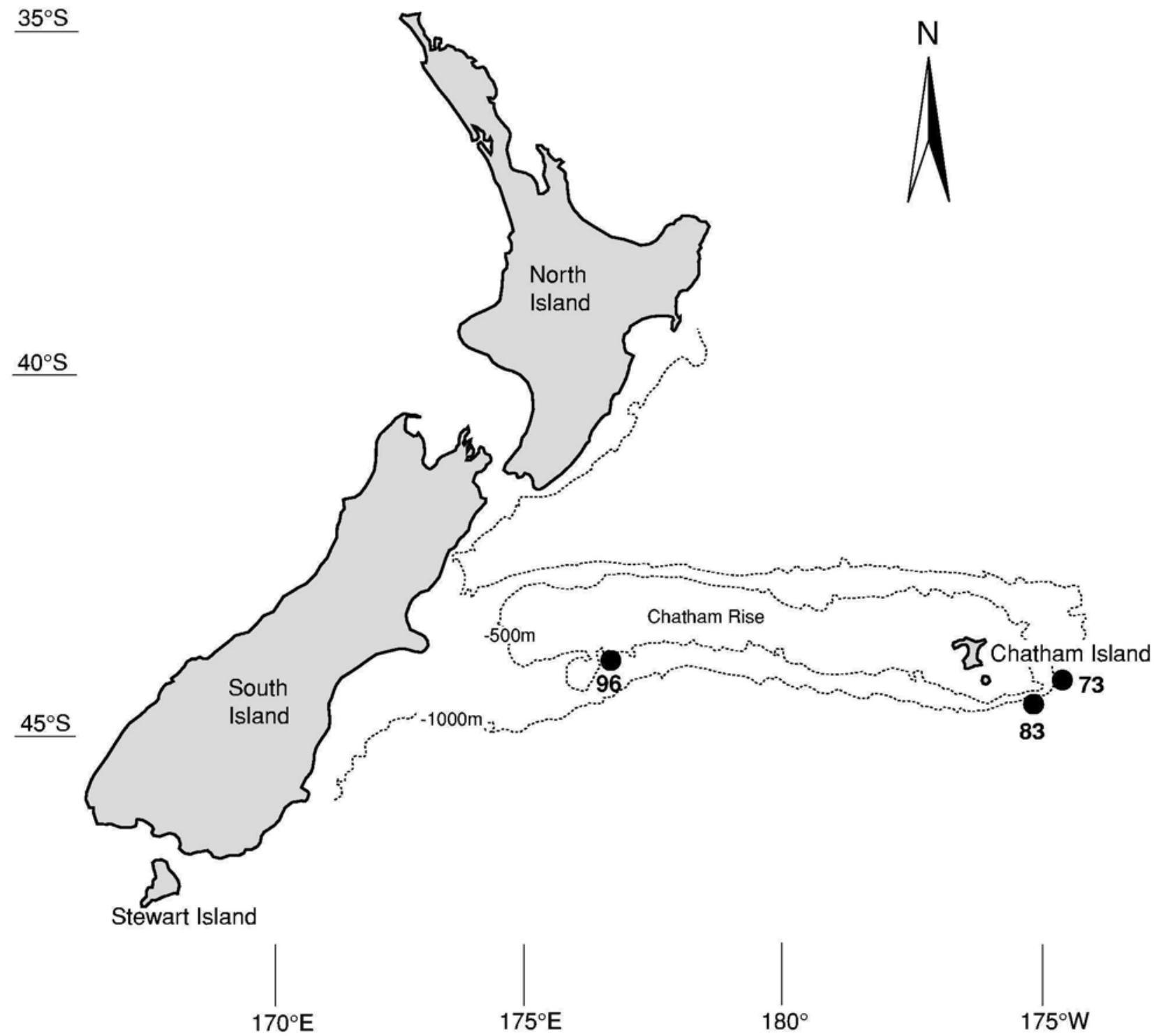

Figure 1 Map of New Zealand, Chatham Island and the Chatham Rise with the three dredging stations 73,83 and 96 , where specimens of Kakanuiella chathamensis sp. nov. were found.

\begin{tabular}{lllll}
\hline Station & Dredge on bottom & Dredge off bottom & Date & Depth \\
73 & $44^{\circ} 12.99^{\prime} \mathrm{S}$ & $44^{\circ} 13.22^{\prime} \mathrm{S}$ & 07 Jan 2003 & $965-874 \mathrm{~m}$ \\
& $174^{\circ} 28.22^{\prime} \mathrm{W}$ & $174^{\circ} 28.90^{\prime} \mathrm{W}$ & & \\
83 & $44^{\circ} 40.833^{\prime} \mathrm{S}$ & $44^{\circ} 40.517^{\prime} \mathrm{S}$ & 08 Jan 2003 & $1024-755 \mathrm{~m}$ \\
& $175^{\circ} 12.754^{\prime} \mathrm{W}$ & $175^{\circ} 12.756^{\prime} \mathrm{W}$ & & \\
96 & $44^{\circ} 03.058^{\prime} \mathrm{S}$ & $44^{\circ} 03.263^{\prime} \mathrm{S}$ & 12 Jan 2003 & $605-405 \mathrm{~m}$ \\
& $176^{\circ} 27.666^{\prime} \mathrm{E}$ & $176^{\circ} 27.608^{\prime} \mathrm{E}$ & & \\
\hline
\end{tabular}

Table 1 Data of dredging stations east of Chatham Island and on the Chatham Rise where rocks with cemented Kakanuiella chathamensis sp. nov. were found.

New Zealand during the cruise SO 168 "ZEALANDIA" with the German research vessel FS SONNE. The brachiopods were cemented by their ventral valves on volcanic rock (basalt) and were found in dense groups in crevices of the irregular rock surface. The rocks were partly covered with thin manganese crusts as were some of the dead brachiopod shells.
Once onboard, rocks were collected from the chain bag of the dredge and immediately searched for brachiopod shells. The animals were freed from the substratum with a scalpel blade and fixed in $96 \%$ ethanol to preserve the DNA for future molecular work. To investigate shell morphology, animals were treated with $3 \%$ sodium hypochlorite solution. 


\begin{tabular}{|c|c|c|c|c|c|}
\hline Specimen & Shell length & Shell width & Sex & Figure & Station \\
\hline H 836 NIWA 3241 (Holotype) & 3.3 & 3.4 & $?$ & $2 \mathrm{~A}$ & 83 \\
\hline P 1386 NIWA 3242 & 2.9 & 3.0 & $f$ & & 83 \\
\hline P 1386 NIWA 3243 & 3.4 & 3.0 & $f$ & & 83 \\
\hline P 1386 NIWA 3244 & 3.1 & 2.5 & $?$ & & 83 \\
\hline BMNH ZB 4590 & 2.6 & 2.7 & $?$ & & 83 \\
\hline BMNH ZB 4591 & 3.0 & 2.9 & $f$ & & 83 \\
\hline BMNH ZB 4592 & $?$ & $3 \cdot 3$ & $f$ & & 83 \\
\hline ZMB Bra 2009 & 2.6 & 2.5 & $\mathrm{~m}$ & $2 \mathrm{~B}, \mathrm{C} ; 3 \mathrm{~A}$ & 73 \\
\hline ZMB Bra 2010 & 3.1 & 2.5 & $f$ & $2 \mathrm{E}, \mathrm{F} ; 3 \mathrm{~B}, \mathrm{C}, \mathrm{F}$ & 73 \\
\hline ZMB Bra 2011 & 3.0 & 3.0 & $?$ & $2 \mathrm{D}, \mathrm{G}$ & 83 \\
\hline ZMB Bra 2012 & 3.2 & 3.1 & $f$ & $2) ; 3 \mathrm{D}$ & 83 \\
\hline ZMB Bra 2013 & 3.0 & 3.2 & $f$ & $2 \mathrm{H} ; 3 \mathrm{E}$ & 83 \\
\hline Mean \pm SD & $3.0 \pm 0.2$ & $2.9 \pm 0.3$ & & & \\
\hline
\end{tabular}

Table 2 Size measurements (in $\mathrm{mm}$ ) of the holotype and all paratypes of Kakanuiella chathamensis sp. nov, dredged at stations 73 and 83 (details see Fig. 1, Table 1). Museum acronyms: NIWA, National Institute of Water \& Atmospheric Research, Wellington, New Zealand; ZMB, Museum für Naturkunde, Berlin; BMNH, The Natural History Museum, London. Abbreviations: $f$, female; m, male.

The dissolved soft tissue was rinsed away with tap water. Shells were left in water for 10-12 hours, then air-dried and gold/platinum sputtered in a Polaron SC7640 sputter coater. Some specimens were critical point dried. Specimens were investigated in a LEO VP 1540 scanning electron microscope. Digital images were edited and finally arranged as photographic panels using Adobe Photoshop ${ }^{(\mathbb{R})} 6.0$ and Adobe Illustrator $^{\circledR} 10$.

\section{Taxonomic description}

The following hierarchical classification is in accordance with volume 5 of the revised Treatise on Invertebrate Paleontology, part H Brachiopoda (see Baker, 2004).

Phylum Brachiopoda Duméril, 1806

Subphylum Rhynchonelliformea Williams et al. 1996

Class Rhynchonellata Williams et al. 1996

Order Thecideida Pajaud, 1970

Suborder Thecideidina Elliott, 1958

Superfamily Thecideoidea Gray, 1840

Family Thecideidae Gray, 1840

Subfamily uncertain (see text)

Genus Kakanuiella Lee and Robinson, 2003

\section{Kakanuiella chathamensis Lüter sp. nov.} Figs 2-3, Tables 1-2

\section{Diagnosis}

An average-sized Kakanuiella with typical median septum inside the ventral valve; median septum slightly resorbed in adults, septum accompanied by sets of calciferous, spiny tubercles on floor of ventral valve; interior of subperipheral margins clearly ribbed in adult ventral valves, dorsal valves with elongate tubercles instead of ribs. Floor of ventral valve symmetrically uplifted like a 'prickly cushion' on either side of median septum. Mantle without obvious spiculation.

\section{Holotype}

One rather large specimen with shell fully intact and closed, sex unknown, cemented on matrix (Mn-crust from a larger altered basalt boulder), collected at Station 83, 9 January 2003, fixed and preserved in $96 \%$ ethanol (Fig. 2A). Accession number $\mathrm{H}$ 836 NIWA 3241, National Institute of Water \& Atmospheric Research (NIWA), Wellington, New Zealand.

\section{Paratypes}

1 male, 7 females (all separated in dorsal and ventral valves) and 3 specimens with closed shells and undetermined sex. All paratypes collected at Station 73, 7 January 2003, and Station 83 , 9 January 2003 , fixed in ethanol, some were critical point dried for SEM inspection. For specimen details and accession numbers see Table 2 .

\section{Etymology}

Named after the type locality Chatham Rise, a submerged part of the New Zealand micro-continent east of the South Island. The morphological terms used in the following description are in accordance with the first comprehensive account of thecideid shell morphology by Williams (1973).

\section{Description}

EXTERIOR. Small-sized thecideid brachiopod with calcified shell, endopunctate, rectimarginate; shape of shell varies depending on attachment position on substrate, usually triangular to heart-shaped in dorsal view with straight hinge line (Fig. 2A, G); both valves rather flat. Ventral valve larger, like a flattened bowl in shape, cemented on the substrate with complete underside of the valve where possible, intact ventral valves with preserved area of first attachment (Fig. 2G); with interarea, flat and triangular in shape, without pseudodeltidium, interarea sometimes slightly curved (Fig. 2A, F, G). Dorsal valve smaller, lid-like, slightly convex, wider than long if not roundish, with irregular growth lines, highest point of dorsal valve sometimes with preserved juvenile shell (Fig. 2D), 


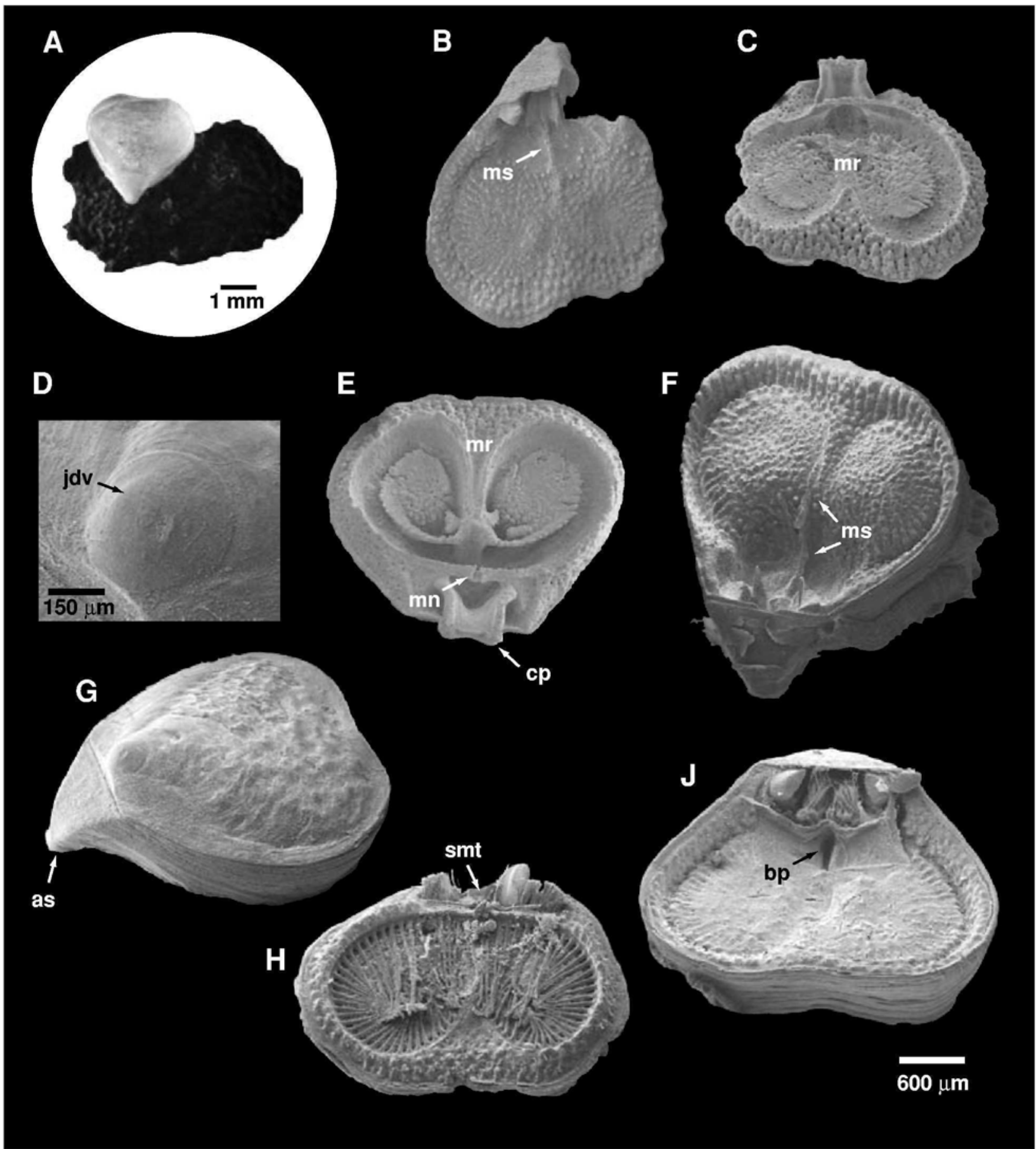

Figure 2 Kakanuiella chathamensis sp. nov. A. Holotype H 836 NIWA 3241, dorsal aspect. The shell is ventrally cemented on a piece of Mn-crust picked from a large basaltic boulder. B. Ventral valve of paratype ZMB Bra 2009 with median septum (ms). C. Dorsal valve of ZMB Bra 2009 with median ridge. D. Detail of dorsal valve of ZMB Bra 2011 with the cap-like juvenile dorsal valve (jdv). E. Dorsal valve of ZMB Bra 2010 with median ridge $(\mathrm{mr})$, marsupial notch $(\mathrm{mn})$ in the bridge and prominent cardinal process (cp). F. Ventral valve of ZMB Bra 2010 with the median septum partly camouflaged by the cushion-like valve floor on either side of the septum. G. ZMB Bra 2011, external aspect of the shell, with straight hinge line and flat interarea, lateral view. Note the first attachment site (as) of the juvenile animal. H. Dorsal valve of ZMB Bra 2013 with preserved lophophore and the pair of specialized median tentacles (smt). J. Ventral valve of ZMB Bra 2012. Note the median, slit-like brood pouch (bp) in the ventral mantle and the subtriangular teeth (broken on the valve's left side).

distance of highest point from hinge line about one third of total valve length.

INTERIOR. Ventral valve with median septum (Fig. 2B, F), clearly defined already in juveniles by a row of interconnected papillae; in adults septum may be partly resorbed or hidden in the frontal two-thirds of the valve by uprising valve floor (Fig. 2F), ventral valve floor like a 'prickly cushion' separated by the median septum (Fig. 2F), septum accompanied by calciferous spines in direct neighbourhood, spines less obvious 

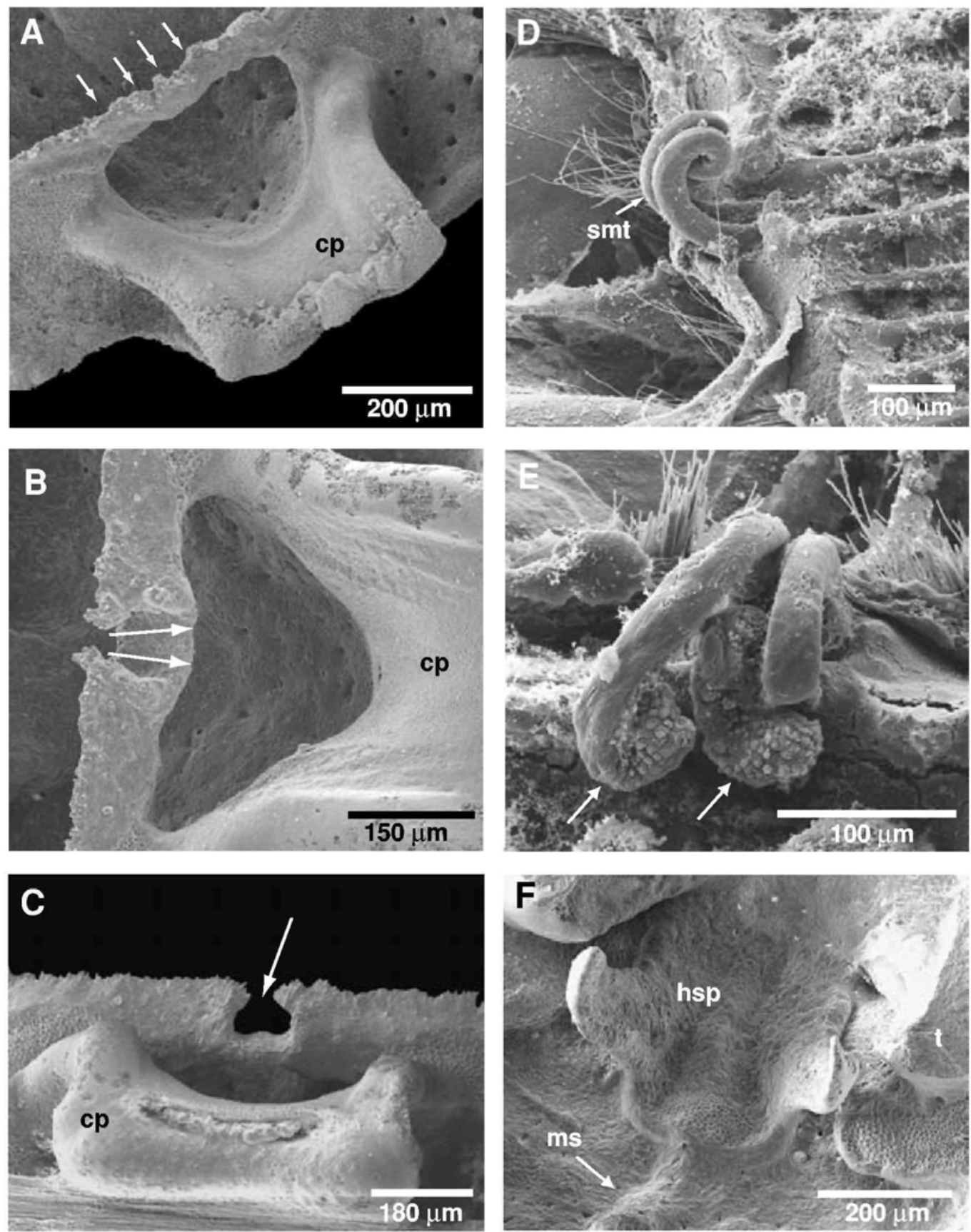

Figure 3 Kakanuiella chathamensis sp. nov. dorsal valves. A. Cardinal process (cp) and bridge of ZMB Bra 2009. Typical male condition with a uniform bridge lacking a marsupial notch (arrows). B. Cardinal process (cp) and bridge of ZMB Bra 2010. Typical female condition with marsupial notch in the bridge. Arrows show where the two specialized tentacles run through the notch. C. Marsupial notch (arrow) of ZMB Bra 2010, caudal view with the concave cardinal process (cp) in front. D. ZMB Bra 2012 with preserved lophophoral tentacles and the two specialized median tentacles (smt), lateral aspect. E. Detail of the median tentacles of ZMB Bra 2013, frontal view. Notice the pyriform tips of the tentacles and their papillose surface (arrows). F. Hemispondylium (hsp) in ventral valve of ZMB Bra 2010, frontal view. Notice the curved prongs on either side of the median septum $(\mathrm{ms})$. Left tooth $(\mathrm{t})$ broken off during preparation.

with distance from the septum, pallial cavity deep only in the caudal one third of the valve, divided into two parts by the median septum. Subperipheral margin of ventral valve with coarsely ribbed sculpture and/or large tubercles (Fig. 2F). Scoop-like hemispondylium (Fig. 3F) with two broad and curved plate-like prongs pointing towards the dorsal valve, base of hemispondylium connected to floor of ventral valve, medially divided by the median septum. Teeth robust and subtriangular in shape (Fig. 2J). Ventral mantle without obvious spicules.

Dorsal valve with median ridge (Fig. 2C, E), median ridge relatively wide anteriorly, ascending, with median groove, tapering posteriorly, median ridge ends at about two thirds of the valve length and gives rise to arch-like intrabrachial ridges, which themselves connect to the interbrachial lobes on either side of the median ridge (Fig. 2E). Interbrachial lobes not 
canopied as in Thecidellina, but solid, massive calcified structures, edges of interbrachial lobes irregularly denticulated, rarely serrated, interbrachial lobes without holes to accommodate brood pouches. Peribrachial ridges caudally connected by a delicate and narrow bridge (Figs $2 \mathrm{C}, \mathrm{E} ; 3 \mathrm{~A}-\mathrm{C}$ ) which reflects sexual dimorphism i.e. males without marsupial notch (Fig. 3A), females with marsupial notch in the middle of the bridge (Figs 2E; 3B, C), accordingly females possess two specialized tentacles running through the marsupial notch and pointing towards ventral valve (Fig. 2H; 3D, E), specialized tentacles with ventral band of cilia and pyriform tips (Fig. 3E), surface of pyriform tips covered with papillae (Fig. 3E) possibly responsible for secretion of a sticky substance as a transient attachment aid for larvae whilst brooded in the pouch; ventral mantle with single wedge-shaped median brood pouch (Fig. 2J). Gonads develop in pallial cavity on the inside of ventral mantle parts, which form the brood pouch. In contrast to Lacazella and Ospreyella gonads lack protective plate-like spicules in ventral mantle. Apart from brood pouch and specialized tentacles soft tissue morphology as in Thecidellina.

\section{Discussion}

Kakanuiella chathamensis sp. nov. represents an unusual thecideid brachiopod, because it displays diagnostic characters of both Recent subfamilies Thecidellininae and Lacazellinae. Since the bridge in the dorsal valve is such a delicate structure, it is often lost during preparation and/or fossilization and, therefore, escaped the attention of previous authors. The original description of the fossil species Thecidellina hedleyi Thomson, 1915 was based on a few imperfectly preserved specimens. Only one dorsal valve was described and drawn. Thomson mentioned that "in front of the socket ridges there are two spurs pointing laterally inwards, probably the remains of a broken bridge" (Thomson, 1915, p. 463). Since all other shell characters - apart from the median septum in the ventral valvemade these brachiopods look like the recent Thecidium barretti, Thomson decided to place the new fossil together with T. barretti in his new genus Thecidellina. This is understandable, when it is also borne in mind that the "interior of [the] ventral valve [of the new fossil species was] unknown' (Thomson, 1915, p. 463). Thomson thus missed the unique character combination of the new species. Only recently, Thecidellina hedleyi was re-described and placed in a new genus Kakanuiella by Lee \& Robinson (2003) on the basis of the median septum in the ventral valve and the morphology of the sculpture of the subperipheral margins in both valves. Lee \& Robinson examined over 200 specimens, including further material from the type locality (Everett's Quarry, Kakanui near Oamaru, New Zealand) plus the type material. Some fossils had preserved bridges showing a marsupial notch, which was noted by the authors, who, however, did not discuss this unusual feature with regard to their classification, which placed Kakanuiella within the subfamily Thecidellininae sensu Elliott $(1953,1958)$. So far, there is no evidence that any member of this subfamily has marsupial notches and, accordingly, specialized tentacles and a single, ventral brood pouch are absent from any living thecidellinine brachiopod. Instead, this character complex is diagnostic for all extant members of Lacazellinae, the other subfamily comprising Recent members of thecideid brachiopods. Lacazelline brachiopods seem to show a $1: 1$ sex ratio (see e.g. Lüter et al., 2003 for Ospreyella depressa). In Kakanuiella very few males were found. Most of the dorsal valves, also in dead shells, showed a bridge with marsupial notch. This can possibly be explained by sample bias due to small sample size (although c. 30 shells were checked for a marsupial notch) or a local rarity of males. Another explanation could be that Kakanuiella is a hermaphrodite, which displays the male condition first and ends up as a female, displaying the notch in the bridge. According to James (1997) such a size- or age-related sequential change of sex has never been observed in brachiopods. However, since hermaphroditism has been discussed for Thecidellina spp. (James et al., 1992; James, 1997; Williams et al., 1997) it may well apply to Kakanuiella. Unfortunately, it was not possible to assess this hypothesis by checking ripe gonads in dissected animals.

The construction of the median ridge and the interbrachial lobes as observed in Kakanuiella without a second set of so-called minor interbrachial lobes cannot be distinguished from the morphology of the dorsal valve interiors in Thecidellina spp. On the other hand, the delicate bridge with a marsupial notch in females likewise observed in Kakanuiella is not seen in any living Thecidellina spp. but is present in all lacazelline brachiopods. Additionally, all Recent Thecidellina spp. have a supporting calcified pole-like structure connecting the bridge and the basis of the cardinal process. This structure is also missing in Kakanuiella. Thus, the caudal part of the dorsal valve of Kakanuiella (bridge to cardinal process) is typical lacazelline, whereas the frontal part (valve margin to median ridge) is typical thecidellinine. In the present state of knowledge, it is impossible to decide which subfamily Kakanuiella belongs to. The interpretation of Kakanuiella as a member of the subfamily Thecidellininae by Lee \& Robinson (2003) can only be accepted as a working hypothesis based on traditional reasons with respect to Thomson's original description of Thecidellina hedleyi. Since we currently do not know the sister taxon of Kakanuiella, a decision whether the marsupial notch and the single, median brood pouch in the ventral mantle are groundpattern characteristics for Thecideidae or apomorphies for a thecideid subgroup cannot be made. The new findings in Recent Kakanuiella do not help to clarify this situation. The difficulties of suprageneric taxonomic assignment of Kakanuiella due to the character mix described in this paper is only one example for our fundamental problems to resolve the phylogeny of the entire group (see above). A phylogenetic analysis of thecideid brachiopods based on morphological and molecular characters is urgently needed and the result may have future nomenclatural implications.

Finally, there is considerable interest in the discovery of living representatives of the shallow water Eocene-Oligocene brachiopod Kakanuiella at depths between 400 and $\sim 1000 \mathrm{~m}$ off New Zealand, since this apparent migration to deep-water is parallelled exactly by the Recent lithistid sponge Pleroma aotea, recently described by Kelly (2003). The sponge was dredged on the Three Kings Ridge and West Norfolk Ridge off northern New Zealand in depths between $486-900 \mathrm{~m}$. Kelly 
et al. (2003) describe Pleroma aotea as a 'living fossil', since its characteristic silica spicules are indistinguishable from those of fossil Pleroma spp. found in late Eocene-early Oligocene shallow-water volcaniclastic sediments at Kakanui. The migration of the sponges could possibly be explained by silica depletion in shallow water after the Eocene, due to increasing diatom abundance (Kelly et al., 2003). Since this cannot explain the assumed migration of thecideid brachiopods, a set of yet undetected environmental changes may have caused the local Eocene benthic community, consisting of lithistid sponges, thecideid brachiopods and other sessile, hard-bottom dwelling invertebrates to migrate from shallow to deeper waters over the last $\sim 35$ million years.

\section{Acknowledgements}

Thanks are due to the scientific party and the crew of FS SONNE during the cruise SO 168 'Zealandia'. Financial support by the German Federal Ministry of Education and Research (BMBF) is gratefully acknowledged (Project: SO 168 - ZEALANDIA, FKZ: 03G0168). I also thank $G$. Drescher for technical assistance with processing the specimens for SEM-investigation and Alan Logan, Daphne Lee and Jeff Robinson for comments on a first draft of this paper.

\section{References}

BACKHAUS, E. 1959. Monographie der cretacischen Thecideidae (Brach.). Mitteilungen des geologischen Staatsinstituts Hamburg 28, 5-90.

BAKER, P. G. 1984. New evidence of a spiriferide ancestor for the Thecideidina (Brachiopoda). Palaeontology 27, 857-866.

BAKER, P. G. 1990. The classification, origin and phylogeny of thecideidine Brachiopods. Palaeontology 33, 175-191.

BAKER, P. G. in press. Thecideida. In: KAESLER, R. L., Ed., Treatise on Invertebrate Paleontology, part H: Brachiopoda, Revised, Vol. 5. The Geological Society of America and University of Kansas Press, Boulder and Lawrence.

CoHEN, B. L. \& GaWTHRoP, A. B. 1997. The brachiopod genome. In: KAESLER, R. L., Ed., Treatise on Invertebrate Paleontology, part H: Brachiopoda, Revised, Vol, 1. The Geological Society of America and University of Kansas Press, Boulder and Lawrence, pp. 189-211.

Cohen, B. L., Gawthrop, A. B. \& Cavalier-Smith, T. 1998 Molecular phylogeny of brachiopods and phoronids on nuclearencoded small subunit ribosomal RNA gene sequences. Philosophical Transactions of the Royal Society, London B 353, 2093 3061.

ElliotT, G. F. 1953. The classification of the thecidean brachiopods. The Annals and Magazine of Natural History, 12, series, 6, 693709.

ElliotT, G. F. 1958. Classification of thecidean brachiopods. Journal of Paleontology, 32373.

Grant, R. E. 1972. The lophophore and feeding mechanism of the Productidina (Brachiopoda). Journal of Paleontology 46, 213-249.

JAECKS, G. S. 2001. Thecideide phylogeny, heterochrony, and the gradual acquisition of characters. In: Brunton, C. H. C., CoCKS,
L. R. M. \& LonG, S. L., Eds., Brachiopods - Past and Present. Taylor \& Francis, London, pp. 240-247.

JAECKS, G. S. \& CARLSON, S. J. 2001. How phylogenetic inference can shape our view of heterochrony: examples from thecideide brachiopods. Paleobiology 27, 205-225.

JAMES, M. A. 1997. Brachiopoda: Internal anatomy, embryology, and development. In: HARRISON, F. W. \& WOOLLACOTT, R. M., Eds., Microscopic anatomy of invertebrates Vol. 13 : Lophophorates, Entoprocta, and Cycliophora. Wiley-Liss, New York, pp. 297407.

James, M. A., Ansell, A. D., Collins, M. J., Curry, G. B., Peck, L. S. \& RHODES, M. C. 1992. Biology of living brachiopods. Advances in Marine Biology 28, 175-387.

KelLY, M. 2003. Revision of the sponge genus Pleroma Sollas (Lithistida: Megamorina: Pleromidae) from New Zealand and New Caledonia, and description of a new species. New Zealand Journal of Marine and Freshwater Research 37, 113-127.

Kelly, M., Lee, D., Kelly, S. \& Buckeridge, J. S. 2003. A recent sponge, Pleroma aotea Kelly ("Order" Lithistida: Family Pleromidae), in the late Eocene Ototara Limestone of Otago, New Zealand. New Zealand Journal of Marine and Freshwater Research 37, 129-148.

MACKINNON, D. I. 1974. The shell structure of spiriferide Brachiopoda. Bulletin of the British Museum of Natural History (Geology) 25, 189-261.

LACAZE-DUTHIERS, H. 1861. Histoire naturelles des brachiopodes vivantes de la Méditerranée. Annales des Sciences Naturelles, série $415,260-330$.

LEE, D. E. \& RoBInson, J. E. 2003. Kakanuiella (gen. nov.) and Thecidellina: Cenozoic and Recent thecideide brachiopods from New Zealand. Journal of the Royal Society of New Zealand 33, 341-361.

LoGAN, A. 1988. A new thecideid genus and species (Brachiopoda, Recent) from the southeast North Atlantic. Journal of Palaeonto$\operatorname{logy}$ 62, 546-551.

LÜTER, C., WÖRHEIDE, G. \& ReITNER, J. 2003. A new thecideid genus and species (Brachiopoda, Recent) from submarine caves of Osprey Reef (Queensland Plateau, Coral Sea, Australia). Journal of Natural History 37, 1423-1432.

Pajaud, D. 1970. Monographie des Thécidées (Brachiopodes). Mémoires de la Société géologique de France (Nouvelle série) 112, 1-345.

Pajaud, D. 1974. Écologie des Thécidées. Lethaia 7, 203-218.

RUDWICK, M. J. S. 1968. The feeding mechanisms and affinities of the Triassic brachiopods Thecospira Zugmayer and Bactrynium Emmrich. Palaeontology 11, 329-360.

THOMSON, J. A. 1915. On a new genus and species of the Thecideiinae. Geological Magazine decade VI, 2, 461-464.

WILliams, A. 1968. Evolution of the shell structure of articulate brachiopods. Special Papers in Palaeontology 2, 155.

WILliams, A. 1973. The secretion and structural evolution of the shell of thecideidine brachiopods. Philosophical Transactions of the Royal Society, London, $B$ 264, 439478.

Williams, A., JAMES, M. A., EMiG, C. C., MACKAY, S. \& RhodeS, M. L. 1997. Anatomy. In: KAESLER, R. L., Ed., Treatise on Invertebrate Paleontology, part H: Brachiopoda, Revised, Vol. 5. The Geological Society of America and University of Kansas Press, Boulder and Lawrence, pp. 7-188. 